\title{
DIAKRONIKA
}

Vol. 17 No. 1 Th. 2017 p: 1-18

ISSN: 1411-1764 (Print) | 2620-9446 (Online)

http://diakronika.ppj.unp.ac.id

\section{Kehidupan Nyai dan Pergundikan Di Jawa Barat Tahun 1900-1942}

\author{
Elfa Michellia Karima \\ elfamichellia.k@gmail.com \\ Universitas Negeri Padang
}

\begin{abstract}
This research discusses on the lives of the people of West Java, especially women who make the practice of concubinage as a livelihood to meet the economic needs of the family. The method used in this research is the historical method with the literature study technique by searching the source of literature. By the high number of native women who became Nyai in West Java, the problem of this research is about the lives of native women when became Nyai to European people. The urgent needs of economy make the women to earn living by working on the farm or became Nyai to European people. There are two kinds of concubinage performed, they are official relationship and unofficial relationship. Concubinage official relationship is a relationship legalized in marriage and legally registered in the Dutch government. However, if the relationship is unofficial, then the marriage is conducted without lawful ties and the absence of law protecting the native women. This has a devastating impact that is the spread of venereal disease among Europeans and Natives.
\end{abstract}

Keywords : Nyai, West Java, Concubinage, Women

\begin{abstract}
Abstrak
Penelitian ini membahas mengenai kehidupan masyarakat Jawa Barat terutama perempuan yang menjadikan praktik pergundikan sebagai salah satu mata pencaharian untuk memenuhi kebutuhan ekonomi keluarga. Metode yang digunakan dalam penelitian ini ialah metode historis dengan teknik studi literatur dengan menelusuri sumber kepustakaan. Dengan banyaknya perempuan Pribumi yang menjadi Nyai di daerah Jawa Barat, maka kajian permasalahannya mengenai kehidupan perempuan Pribumi ketika menjadi seorang Nyai pada orang Eropa. Kebutuhan akan ekonomi yang mendesak membuat perempuan ikut mencari nafkah dengan bekerja di perkebunan ataupun menjadi Nyai pada orang Eropa. Adapun dua macam hubungan pergundikan yang banyak dilakukan, yaitu hubungan resmi dan tidak resmi. Hubungan pergundikan resmi yaitu hubungan yang disahkan dalam pernikahan dan didaftarkan secara hukum pada pemerintahan Belanda. Namun, apabila hubungan tidak resmi maka pernikahan dilakukan tanpa adanya ikatan sah dan tidak adanya hukum yang melindungi perempuan Pribumi. hal ini memiliki dampak yang meresahkan yaitu menyebarnya penyakit kelamin di kalangan orang Eropa dan Pribumi.
\end{abstract}

Kata Kunci: Nyai, Jawa Barat, Pergundikan, Perempuan 


\section{Pendahuluan}

Perekonomian Pribumi sangat tergantung pada politik yang dijalankan oleh pemerintah Kolonial. Sebagai negara jajahan yang berfungsi sebagai daerah eksploitasi untuk memenuhi kebutuhan negara induk, Pemerintah Hindia Belanda menggunakan sistem perekonomian yang menguntungkan negara induk. Maraknya perdagangan hasil pertanian, Belanda memberlakukan sistem produksi hasil pertanian. Belanda mewajibkan setiap masyarakat Pribumi untuk bekerja wajib dan melakukan penanaman wajib untuk menghasilkan komoditi yang laku di pasaran dunia. Sehingga, penduduk Jawa Barat diwajibkan untuk menanami lahan pertaniannya dengan tanaman tertentu seperti kopi, teh, lada, kina, dan tembakau yang hasilnya dibeli oleh pemerintah Belanda. Berbeda dengan pemerintah Belanda, perusahaan swasta yang diberi keleluasaan untuk menanamkan modalnya di Hindia Belanda membuka lapangan pekerjaan bagi penduduk sebagai pekerja upah perkebunan. Dengan bekerja sebagai buruh upah maka perusahaan swasta akan membayarnya dengan uang. Inilah yang menjadi awal perkembangan pengenalan nilai mata uang atau monetisasi pada penduduk Priangan. Keperluan akan uang sebagai pemenuh kebutuhan keluarga mengakibatkan kerja upah di perkebunan tidak hanya dilakukan oleh laki-laki Pribumi, melainkan juga oleh perempuan Pribumi dan anak-anak.

Demi mendapatkan pendapatan untuk memenuhi kebutuhan keluarga, tidak sedikit perempuan yang bekerja sebagai Nyai pada pejabat daerah ataupun pada pegawai Belanda. Nyai merupakan panggilan untuk seorang perempuan yang belum atau sudah menikah atau panggilan untuk seorang perempuan yang usianya lebih tua dari orang yang memanggil. Selain itu Nyai juga sebutan untuk gundik orang asing (terutama orang Eropa). Sementara itu Gundik ialah istri tidak resmi atau perempuan "piaraan". Nyai dalam penulisan ini ialah yang merujuk pada perempuan "piaraan" atau istri simpanan dari orang Eropa yang berperan untuk melayani dan mengurus rumah tangga. Sehingga dapat diartikan bahwa Nyai atau gundik adalah seorang istri tidak resmi atau selir yang mengatur rumah tangga dan juga memenuhi kebutuhan biologis laki-laki Eropa, serta menjadi ibu bagi anak-anak hasil hubungannya. Di samping itu, para gundik juga sering disebut dengan Meubel (perabot), atau Inventarisstuk (barang inventaris) (Baay, 2010). Menurut Bakthin (Bakhtin, 1997) panggilan Nyai memiliki beberapa makna baik itu makna yang dikembangkan oleh Bangsa Belanda maupun yang beredar di kalangan masyarakat Pribumi.

" There is clearly a multiplicity of social and linguistic perspectives at work in the adaptation of the term nyai to define the status of a native "concubine," "housekeeper," or "mistress" in a colonial Dutch East Indies household. The specifically Javanese form of respectful address changes 
considerably in translation into the euphemistic, pejorative, and disrespectful colonial "judgment" on the nyai. It becomes an international coinage an effect of what Bakhtin calls "heteroglossia"-caught, as the nyai herself is, between the world of native Javanese family values affairs".

Kebutuhan ekonomi mendesak telah membuat perempuan Pribumi yang berprofesi sebagai Nyai mengabaikan penggilan yang merendahkannya. Salah satu adanya praktek pergundikan yang dilakukan Nyai menurut Mitchell ialah karena adanya kultural patriarki yang tumbuh di kalangan masyarakat Hindia Belanda(Thornham, 2010). Ketundukan sang gadis pada "hukum sang ayah' yang membentuk dirinya sendiri sebagai lawannya.

Dampak pergundikan yang sangat merugikan seolah diabaikan, perempuan Pribumi bekerja sebagai Nyai. Desakan akan kebutuhan ekonomi menjadi salah satu penyebab maraknya pergundikan pada masa Kolonial. Selain itu, faktor kehidupan masyarakat Jawa Barat sangat kental dengan peraturan adat istiadat terutama yang mengatur perempuan untuk tunduk dan patuh terhadap ayah, suami atau saudara laki-laki dalam keluarganya, apapun yang diperintahkan kepada perempuan tersebut harus dijalani dengan senang hati dan tanpa bantahan.

Menutupi kebutuhan ekonomi keluarga, tak jarang keluarga menjadikan anak atau saudara perempuannya menjadi Nyai orang Eropa dianggap memiliki kedudukan dan mapan secara ekonomi. Keluarga yang telah menyerahkan anak atau saudara perempuannya kepada orang Eropa dijadikan Nyai akan mendapatkan imbalan. Selain itu, hal ini juga dianggap dapat menaikan prestise keluarga di tengah masyarakat meskipun tidak jarang menuai kecaman karena tidak sesuai dengan agama yang mereka anut.

\section{Metode Penelitian}

Metode penelitian sejarah menurut Gottstchalk (Gottschalk, 1983) adalah menguji dan menganalisis secara kritis rekaman dan peninggalan masa lampau, sedangkan menurut Sjamsudin metode sejarah adalah sebagai salah satu cara bagaimana mengetahui sejarah(Sjamsuddin, 2007). The New Lexicon Webster's dictionary of the English Language dalam buku Sjamsudin mengungkapkan bahwa metode ialah "suatu cara untuk berbuat sesuatu; suatu prosedur untuk mengerjakan sesuatu keteraturan dalam berbuat, berencana, dll suatu susunan atau sistem yang teratur"(Sjamsuddin, 2007).

Penelitian ini menggunakan metode historis dalam mengkaji permasalahan, menurut Ismaun (Ismaun, 2005) metode historis merupakan proses untuk menguji dan mengkaji kebenaran rekaman dan peninggalan masa lampau dengan menganalisis secara kritis bukti-bukti dan data-data yang ada 
sehingga menjadi penyajian dan cerita sejarah yang dapat dipercaya. Adapun enam tahap yang harus ditempuh dalam penelitian sejarah menurut Helius Sjamsudin, yaitu :

a. Memilih suatu topik yang sesuai

b. Mengusut semua evidensi (bukti) yang relevan dengan topik

c. Membuat catatan tentang itu, apa saja yang dianggap penting dan relevan dengan topik yang ditemukan ketika penelitian sedang berlangsung (menggunakan system cards); sekarang dengan adanya fotokopi, komputer, internet menjadi lebih mudah dan membuat system cards "ketinggalan zaman"

d. Mengevaluasi secara kritis semua evidensi yang telah dikumpulkan (kritik sumber)

e. Menyusun hasil-hasil penelitian (catatan fakta-fakta) ke dalam suatu pola yang benar dan berarti yaitu sistematika tertentu yang telah disiapkan sebelumnya

f. Menyajikan suatu cara yang menarik perhatian dan mengkomunikasikannya kepada para pembaca sehingga dapat dimengerti sejelas mungkin (Sjamsuddin, 2007).

Teknik analisis data dilakukan sesuai dengan yang dikemukakan oleh Ismaun, yaitu; Heuristik (pengumpulan sumber-sumber sejarah), Kritik eksternal dan internal (menilai sumber sejarah), Interpretasi (menafsirkan sumber sejarah), Historiografi (penulisan sejarah).

\section{Hasil Penelitian}

Perkebunan sebagai mata pencaharian utama kehidupan masyarakat masa Kolonial telah mengalami proses perkembangan yang cukup panjang. Biasanya usaha perkebunan ini dilakukan oleh sekelompok orang yang menetap di daerah tertentu dan memiliki lahan yang cukup luas untuk ditanami tumbuhan. Tanah yang subur dan iklim yang baik menjadikan Jawa Barat sebagai salah satu daerah perkebunan penting di Nusantara. Dengan dikuasainya Priangan oleh Kolonial dan berkembangnya komoditas teh di pasaran dunia mendorong pemerintah Belanda untuk mendirikan banyak perkebunan. Pada awalnya sistem perekonomian penduduk Jawa Barat menggunakan sistem barter. Di priangan misalnya dipertukarkan kopi dengan garam, candu dan barang-barang dagangan, dan selanjutnya beras dengan garam, kapas belao dan buah-buahan, jarang sekali dengan uang (Burger, 1962).

Jawa Barat memegang peranan penting sebagai penghasil teh di Nusantara yang dikenal dengan sebutan Java Tea. Bagi Belanda komoditas teh 
yang banyak diproduksi di Jawa Barat merupakan pemasukan yang menguntungkan, namun berbeda dengan apa yang dirasakan oleh penduduk Jawa Barat yang bekerja sebagai petani.

Bagi tanah yang disewakan pada pejabat akan menggunakan sistem bagi hasil juga dilakukan oleh penduduk yang tidak memiliki tanah ataupun sawah. Mereka biasanya menyewa tanah ataupun sawah selama satu tahun pada pemilik tanah yang biasanya sesama orang Pribumi, kemudian penyewa tanah akan menggarapnya. Mereka membayar uang sewa dengan melakukan sistem bagi hasil sesuai dengan kesepakatan yang mereka buat. Sistem bagi hasil ini juga banyak dilakukan oleh para bupati sebagai sumber pendapatan dalam bentuk pengabdian umum penduduk. Pada waktu itu, besarnya imbalan untuk pemakaian tanah adalah $1 / 4,1 / 3$, atau $1 / 2$ kadang-kadang juga $2 / 3$, atau $3 / 4$ dari hasil panen(Scheltema, A. M. P. A., Wiradi, G., \& Suyono, 1985).

Banyak perusahaan swasta masuk ke wilayah Jawa Barat untuk menyewa tanah baik pada negara ataupun pada masyarakat kemudian mendirikan perkebunan teh. Pengusaha swasta dapat menyewa tanah selama jangka waktu yang ditentukan dan pengusaha swasta itupun memiliki hak untuk menjadikan tanah sebagai perkebunan. Rata-rata perusahaan swasta yang mendirikan perkebunan di atas tanah sewa ditanami tanaman keras, seperti karet, kopi, teh, dan kina yang dapat dipanen berulang-ulang.

Keadaan Jawa Barat yang masih bersifat tradisional dimanfaatkan oleh perusahaan swasta untuk menarik minat banyak tenaga kerja upah. Mereka bekerja sama dengan pemuka desa yang disegani dan dipatuhi oleh masyarakat sehingga banyak masyarakat yang setuju untuk bekerja upah.

Kerja upah di perkebunan tidak hanya dilakukan oleh laki-laki Pribumi saja, melainkan juga oleh perempuan Pribumi yang membantu memenuhi kebutuhan keluarga. Perusahaan swasta banyak mempekerjakan anak-anak dan perempuan sebagai buruh upah di perkebunan teh ketika datang musim panen, anak-anak bekerja sebagai buruh lepas mencari ulat di perkebunan dan perempuan Pribumi bekerja sebagai pemetik teh. Ketelitian yang diperlukan ketika memetik teh sangat diperlukan untuk mendapatkan kualitas yang baik. Berikut disajikan gambar buruh upah perkebunan teh Jawa Barat. 


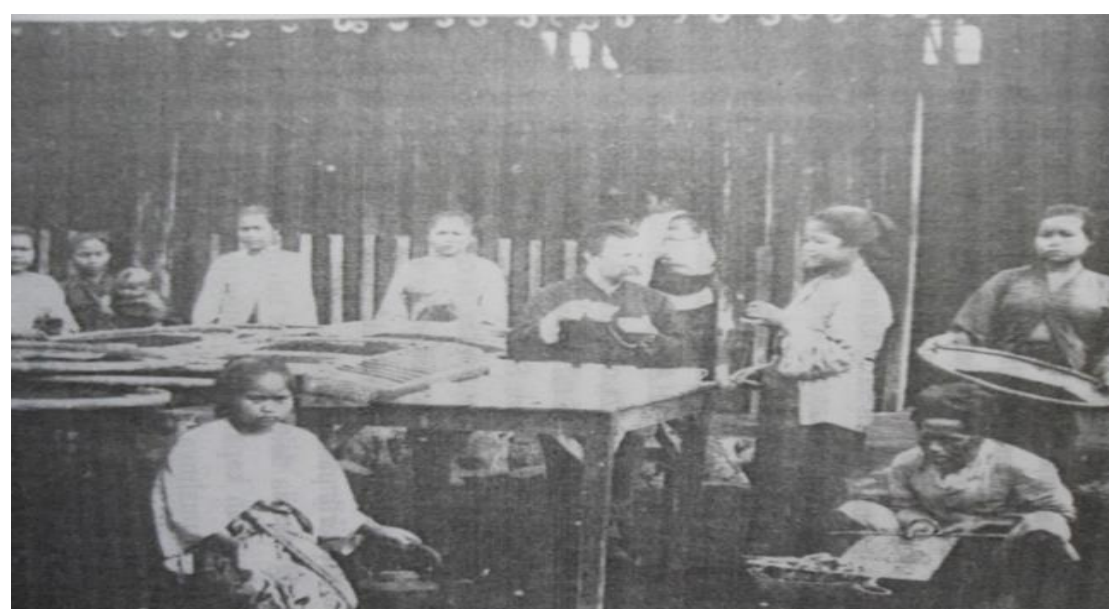

Gambar 1: Buruh Upah Perkebunan Teh Jawa Barat

Sumber: Hellwig, T. (2007). Citra Kaum Perempuan di Hindia Belanda. Jakarta : Yayasan Obor Indonesia : hal 90

Tenaga kerja perempuan ini didapat dari kalangan masyarakat miskin, selain itu posisi mereka di perkebunan merupakan posisi paling rendah sehingga mendapatkan upah yang tidak seberapa bila dibandingkan dengan kebutuhan keluarga yang cukup besar.

Bila dibandingkan dengan pekerja laki-laki bayaran mereka jauh lebih rendah. Sebuah perusahaan besar rata-rata membayar sebesar 2,5 gulden per bulan kepada perempuan(Baay, 2010). Sistem yang berlaku di Jawa Barat, terutama kalangan masyarakat Sunda sangat dipengaruhi oleh adat kebiasaan turun temurun dan oleh agama Islam yang telah lama melekat dalam kehidupan masyarakat. Karena agama Islam telah lama dipeluk oleh orang Sunda, maka susah kiranya untuk memisahkan mana adat dan mana agama, dan biasanya kedua unsur itu terjalin erat menjadi adat kebiasaan dan kebudayaan orang Sunda (Koentjaraningrat, 1988). Dalam sebuah keluarga Sunda keluarga yang terpenting adalah keluarga batih yang terdiri dari ayah, ibu dan anak-anak. Karena masih memegang budaya patriarki maka anggota keluarga laki-laki lah yang memegang peranan penting untuk memutuskan sesuatu, dan perempuan hanya boleh menuruti perkataan laki-laki tanpa adanya penolakan. Hubungan patriarki juga terlihat dalam sistem pernikahan masyarakat Sunda. Kadang-kadang dalam masyarakat Sunda dikenal pula keluarga poligami, yaitu seorang laki-laki mempunyai lebih dari seorang istri (Ekadjati, 1984).

Pada umumnya pernikahan dilakukan antara sesama masyarakat kebanyakan, namun juga tidak sedikit perempuan Pribumi yang menikah dengan seorang pejabat daerah seperti dengan seorang Bupati. Meskipun pernikahan yang terjadi bukanlah pernikahan sah yang sesuai dengan hukum dan agama melainkan perempuan Pribumi dijadikan seorang Nyai. Seorang 
Bupati atau pejabat daerah lainnya dapat memiliki beberapa Nyai merupakan kebiasaan yang sudah kental di kalangan masyarakat. Tidak jarang juga keluarga yang mengaharapkan anak perempuannya untuk menjadi Nyai orang Eropa.

Dalam sebuah kelompok sosial masyarakat Sunda dikenal kelompok orang kaya (jelema beunghar atau jegud) dan orang miskin, pengelompokannya didasarkan atas kekayaan atau prestise yang dimiliki oleh suatu keluarga. Selain kebutuhan ekonomi, pengelompokan inilah yang biasanya dijadikan patokan keluarga dalam menjalani kehidupan. Maka setiap keluarga akan mengusahakan sesuai dengan kemampuan masing-masing untuk mendapatkan posisi yang dirasakan menguntungkan.

Bentuk keluarga dalam masyarakat Sunda dipengaruhi oleh kebiasaan lingkungan dan kepribadian setiap orang, yaitu selalu ingin berkumpul bersama-sama dengan keluarga atau kerabat. Tidak mengherankan apabila dalam satu rumah terdapat beberapa keluarga karena mereka akan merasa aman apabila tinggal bersama dalam satu rumah. Kebersamaan itu ditunjukan ketika salah satu sanak saudara mereka ada yang akan bekerja ke luar kota atau menuju tempat yang jauh, maka mereka akan ikut melepasnya dan ada perasaan perpisahan yang dalam. Hal ini merupakan salah satu sebab mengapa orang-orang Sunda tidak suka merantau (Ekadjati, 1984).

Tinggal bersama dengan keluarga besar mengharuskan setiap pasangan baru yang telah menikah memiliki kewajiban untuk ikut dalam membiayai kebutuhan keluarga besar. Perekonomian keluarga dalam satu rumah ditanggung bersama oleh setiap anggota keluarga. Maka tidak hanya laki-laki, perempuan juga ikut bekerja membantu ekonomi keluarga. Bagi perempuan kebanyakan yang ikut bekerja mencari nafkah bagi keluarga biasanya bekerja di perkebunan teh milik swasta atau bekerja menggarap tanah milik pejabat daerah.

Kewajiban untuk ikut membantu perekonomian keluarga terlihat ketika ekonomi masyarakat Pribumi pada akhir abad ke-19 karena terjadi ledakan penduduk dengan jumlah penduduk dua kali lipat dari jumlah awal. Bencana kelaparan pun sempat melanda penduduk Pribumi sehingga tidak sedikit masyarakat Pribumi meninggal karena kelaparan atau karena serangan berbagai macam penyakit. Pada tahun 1795 Pulau Jawa berpenduduk sekitar 3 juta jiwa, pada tahun 1850 jumlah ini meningkat menjadi 9,4 juta jiwa, dan pada tahun 1890, 23,6 juta jiwa yang mengakibatkan hasil padi tidak cukup memberi makan dalam jumlah ini (Hellwig, 2007).

Pada masa Kolonial tingkat pengangguran, kemiskinan, dan kejahatan cukup tinggi. Hal ini karena sempitnya lahan pekerjaan yang mungkin bisa 
dimasuki oleh masyarakat Pribumi, sehingga banyak perempuan yang masuk ke dunia prostitusi. Pada masa Kolonial cukup banyak perempuan yang bekerja di berbagai bidang tujuannya memenuhi kebutuhan keluarganya karena harga bahan pokok makanan yang melambung tinggi. Seorang perempuan juga memiliki kewajiban yang sama dengan laki-laki dalam bekerja untuk memenuhi kebutuhan keluarga. Hal ini salah satunya karena upah yang diberikan pihak perkebunan pada pekerja laki-laki jauh dari cukup, sehingga perempuan dituntut untuk ikut membantu laki-laki dalam memenuhi kebutuhan ekonomi keluarga meskipun pekerjaan itu berat dan kurang cocok dengan perempuan.

Perkebunan yang didirikan oleh perusahaan swasta menjadikan banyak kelompok pekerja baru berkebangsaan Eropa datang ke Hindia Belanda. Untuk menarik minat pekerja Eropa, tidak jarang perusahaan swasta memberikan imbalan seperti tunjangan yang lebih tinggi dibandingkan dengan bekerja di Belanda. Hak-hak pensiun pun diberikan bagi mereka yang bersedia bekerja di tanah koloni, sehingga pada tahun 1930 terdapat peningkatan jumlah tenaga kerja Belanda yaitu sekitar tujuh kali lipat dari tahun 1895. Kekuasaan dan perintah yang patut dituruti menjadi ciri khas masyarakat Pribumi ketika melihat sosok orang Eropa yang baru saja datang, meski mereka dari kalangan rendahan di tanah kelahirannya. Dengan warna kulit putih mereka dapat menjadi berkuasa di tanah koloni dan mendapatkan kedudukan yang lebih baik.

Pada masa Kolonial terdapat dua tipe hubungan seksual yang banyak dilakukan oleh pegawai berkebangsaan Belanda terhadap perempuan Pribumi, yaitu praktik pelacuran dan pergundikan. Praktik pelacuran merupakan hubungan seksual yang dilakukan dengan sering berganti pasangan dalam jangka waktu yang singkat. Biasanya dilakukan oleh pegawai pemerintah Belanda dalam bidang militer (tentara Belanda). Akibat maraknya pelacuran ini penyakit kelamin menyebar dikalangan tentara Belanda dan perempuan Pribumi karena mereka lebih sering melakukan praktik pelacuran dibandingkan dengan pegawai sipil Belanda. Bagi tentara sulit untuk memiliki rumah tetap yang digunakan sebagai tempat tinggal Nyai, karena tugas mereka yang berpindah-pindah. Oleh karena itu mereka lebih sering pergi ke rumah pelacuran untuk memenuhi kebutuhan biologis.

Tahun 1870, misalnya, terdapat 575 orang yang menderita sifilis dan 5.105 menderita veneri morbis (Jelani, 2013). Dengan maraknya penyebaran penyakit kelamin dan adanya peraturan tersebut maka pegawai pemerintah sipil dan pegawai perusahaan swasta yang bekerja di perkebunan-perkebunan lebih memilih praktik pergundikan dibanding praktik pelacuran. Praktik pergundikan yang banyak dilakukan ialah tinggal bersama perempuan Pribumi 
dalam satu rumah, biasanya bersifat sementara yaitu selama laki-laki Eropa tinggal di daerah tersebut.

Perempuan Pribumi yang bekerja sebagai seorang Nyai memiliki kehidupan yang sulit di tempat asal mereka. Pada mulanya mereka bekerja sebagai pembantu rumah tangga di rumah orang Eropa yang bekerja di perkebunan atau menjadi petani perkebunan. Bila orang Eropa tertarik dengan perempuan Pribumi, maka akan diminta menjadi Nyai. Perilaku orang Eropa ini melihat kebiasaan dari pejabat daerah yang sudah lama mempraktikan pergundikan sehingga menjadi suatu hal yang wajar dalam kehidupan seharihari.

Perempuan yang bersedia jadi Nyai akan merasa senang karena banyak keuntungan didapat meskipun mereka menyadari bahwa akan ada kerugian yang mereka dapatkan juga. Dengan menjadi Nyai seorang pejabat daerah maka pihak keluarga akan merasa senang karena sebuah keluarga dari kalangan rendahan memiliki hubungan dengan keluarga di kalangan atas.

Perempuan Pribumi bersama mandor perkebunan yang berkebangsaan Belanda menjadi pemandangan biasa pada masa Kolonial. Bekerja di perkebunan merupakan salah satu peluang untuk menghasilkan pendapatan. Pakaian yang dipakai pekerja yang lusuh mencerminkan kedudukan yang tidak tinggi di lingkungan masyarakat dan berasal dari kalangan rendahan. Kebahagiaan oleh perempuan Pribumi yang dijadikan Nyai karena mendapatkan hak-hak istimewa tidak dirasakan selamanya, karena apabila sudah tidak dibutuhkan lagi ataupun posisinya akan digantikan dengan perempuan lain maka Nyai itu harus keluar dari rumah.

Meskipun mereka memiliki anak hasil dari hubungannya, namun anak bukanlah suatu jaminan bahwa mereka akan selamanya bersama. Kebiasaan ini telah mengakar dalam kehidupan masyarakat tidak dapat dihilangkan begitu saja. Jumlah perempuan Pribumi yang menjadi seorang Nyai bertambah pesat seiring dengan jumlah orang Eropa yang datang ke pulau Jawa. Perempuan Pribumi yang bekerja sebagai Nyai ialah mereka yang menginginkan penghidupan lebih baik dari sebelumnya sehingga melakukan berbagai macam cara untuk memenuhi gaya hidup yang melebihi perempuan kebanyakan.

\section{Pembahasan}

Kehidupan pergundikan di tengah masyarakat Jawa Barat antara perempuan Pribumi dan laki-laki Eropa sudah menjadi hal yang umum. Pergundikan merupakan kebiasaan yang banyak dilakukan oleh masyarakat Pribumi ketika masa Kolonial. Tidak sedikit keluarga Pribumi yang setuju anak perempuannya dijadikan Nyai oleh orang Eropa karena hal itu dapat menaikan 
status sosial mereka di dalam masyarakat. Kebanyakan keluarga yang menyetujui anak atau sanak saudaranya menjadi Nyai ialah dari kalangan rendahan.

Pergundikan tidak didaftarkan dan dilakukan tanpa diketahui oleh pemerintah Belanda cukup banyak dilakukan oleh orang Eropa karena mereka cenderung berganti gundik dengan hubungan yang tidak terikat. Nyai yang tidak dinikahi atau hubungan itu dilakukan secara sembunyi-sembunyi, maka mereka tidak akan mendapatkan hak istimewa seperti yang diketahui Nyai berstatus resmi. Perbedaan itu dapat terlihat dari perlakuan yang kerap diterimanya, karena Nyai tidak resmi ini kedudukannya sebagai istri simpanan.

Mereka tidak diperlakukan layaknya istri sah, mereka pun terkadang dilarang untuk bertemu dengan kerabat "suaminya" yang datang bertamu ke rumah. Nyai hanya bertugas untuk mengurus rumah tangga dan melayani "suami" meskipun kedudukannya jauh lebih baik dibandingkan dengan pembantu rumah tangga. Pakaian yang dikenakan oleh seorang Nyai yang tidak diakui secara sah tidak akan berbeda jauh dengan pakaian pembantu rumah tangga pada umumnya. Mereka mungkin mengenakan pakaian berenda, namun pakaian itu tidak akan dipakai dalam jangka waktu yang panjang.

Bagi Nyai yang tidak dinikahi secara resmi sering mendapatkan perlakuan yang tidak baik dari "suaminya", tidak jarang mereka menjadi korban luapan emosi dengan perlakuan kasar. Tidak jarang surat-surat kabar mengabarkan mengenai perlakuan yang kerap kali diterima oleh Nyai, namun karena orang kulit putih memiliki kedudukan yang lebih tinggi dari pada penduduk Pribumi, maka Nyai tidak berani untuk mengadukan orang Eropa tersebut. Seperti berita dalam Bataviaasch Nieuwsblad (Baay, 2010), berisikan pemberitahuan tentang perlakuan kasar yang kerap diterima oleh seorang Nyai.

"Baik sang ayah maupun sang anak memukul perempuan tak berdaya itu dengan penuh nafsu. Ketika mereka merasa kelelahan setelah memukul, sang korban pun telah berlumuran darah dengan luka-luka di sekujur tubuhnya. Kemudian ia diancam akan dibunuh jika sekali lagi mengeluh. Lalu ia diperintahkan untuk mencuci sendiri pakaiannya yang penuh darah di sumur untuk menghilangkan bekas-bekas penganiayaan". 
Pergundikan di kalangan militer, Nyai tinggal bersama dalam tangsi militer. Hal ini disebabkan karena kebutuhan akan jumlah pasukan militer Belanda (KNIL) yang besar menjadikan pergundikan sebagai daya tarik tersendiri. Dengan diizinkannya untuk melakukan praktek pergundikan atau memiliki Nyai membuat banyak orang bersedia untuk menjadi tentara KNIL. KNIL kemudian menjadi satu-satunya ketentaraan yang secara resmi mengizinkan serdadunya untuk tinggal bersama, tanpa ikatan pernikahan, dengan perempuan di dalam tangsi (Baay, 2010).

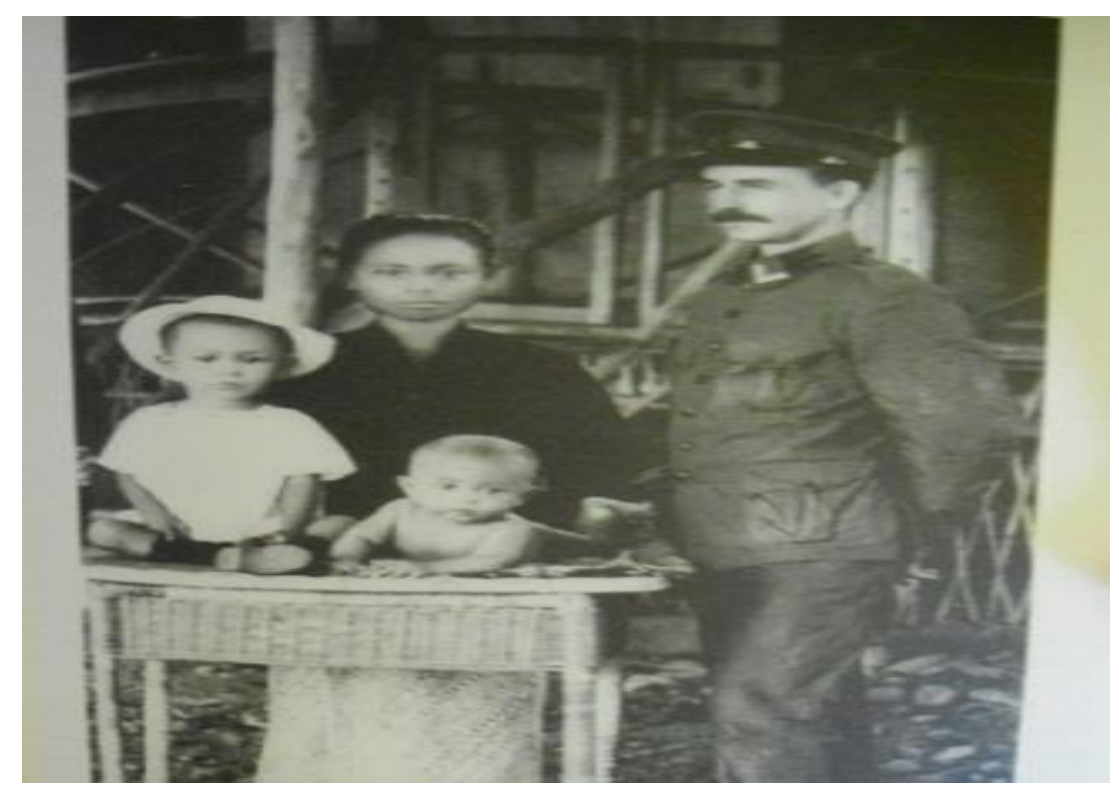

Gambar 2. Nyai Djoemiha bersama dengan keluarga (1918)

Sumber: Baay, R. (2010). Nyai dan Pergundikan di Hindia Belanda. Jakarta : Komunitas Bambu, hal 247

Bagi anggota militer yang memilih untuk melakukan praktek pergundikan ada beberapa syarat khusus yang harus dipenuhi sebelum mereka dapat tinggal bersama di dalam tangsi. Perempuan Pribumi yang bersangkutan diharuskan untuk menyerahkan surat kelakuan baik secara resmi pada panglima militer untuk mendapatkan izin. Setelah mendapatkan izin maka mereka akan di data secara

Khusus seperti pendataan nama, tempat tinggal, dan nama anggota militer yang menjadikannya Nyai. Dengan keluarnya surat izin resmi, Nyai dapat tinggal bersama dengan anggota militer itu di dalam tangsi.

Bagi keluarga yang memiliki banyak anak, mereka akan menggunakan kolong tempat tidur yang dengan dialasi tikar sebagai tempat tidur bagi anak mereka. Sehingga marak sebutan "anak kolong” yang ditujukan bagi anak berdarah campuran yang tidur di bawah tempat tidur orang tua mereka. Tidak ada ruang tambahan yang diberikan pada keluarga yang memiliki banyak anak karena keterbatasan tempat. Yang menjadi ciri khas pergundikan tangsi ialah 
baik perempuan ataupun anak-anak harus patuh dan tunduk pada peraturan militer yang berlaku (Reglement op Den Inwendigen Dienst). "The social significance of the term nyai emerges not just from the contending moral and social perspectives of stories circulated in Dutch" (Gogwilt, 2007).

Pada awalnya perizinan memiliki Nyai ini diberikan oleh pihak militer Belanda dengan pertimbangan bahwa perempuan yang menjadi Nyai di dalam tangsi ini dapat memberikan keuntungan bagi serdadunya karena dapat mengurus "suaminya”. Meski mendapatkan bayaran yang tidak seberapa, bagi perempuan yang menjadi Nyai hal ini adalah sebuah kesempatan untuk lepas dari kemiskinan.

Memiliki Nyai dalam tangsi militer tidak hanya dilakukan oleh anggota militer KNIL berasal dari Eropa saja. Kebiasaan ini juga ditiru oleh anggota militer KNIL asal Afrika yang ditempatkan di Hindia Belanda. Peraturan yang ditetapkan pada seradadu asal Afrika ini juga sama dengan seradadu asal Eropa, misalnya peraturan bahwa setiap seradadu yang didatangkan ke Hindia Belanda harus beragama Kristen. Bagi serdadu asal Eropa hal ini merupakan kepercayaan yang memang dianutnya sejak lahir namun berbeda dengan sserdadu Afrika yang kebanyakan tidak beragama Kristen. Oleh karena itu, banyak pembaptisan seperti yang terjadi di Hindia Belanda kepada serdadu asal Afrika. Peraturan ini ditetapkan untuk dapat mengikuti aturan yang terdapat di Hindia Belanda selanjutnya, misalnya dalam hal pernikahan. Meskipun memang hak yang ditetapkan tidak sepenuhnya sama namun peraturan untuk menciptakan kedisiplinan ditetapkan sama.

Seorang Nyai yang memiliki status sah dalam pernikahannya dan diakui secara hukum akan mendapatkan hak-hak seperti seorang istri sah lainnya. Mereka mendapatkan perlakuan yang sama ketika bertemu dengan warga Eropa lainnya. Dengan adanya hubungan yang cukup erat dengan warga Eropa maka penampilan Nyai kerap kali mengikuti penampilan ala Eropa. Namun, tidak sepenuhnya sama hanya saja mereka mengadaptasi dan mencampurkannya dengan kebudayaan asli Priangan. Dari mulai cara berpakaian hingga asesoris yang dipakai. Banyak Nyai memakai pakaian yang pada umumnya dipasangi renda, pada masa itu renda merupakan barang yang mahal dan dipakai hanya oleh orang-orang tertentu saja. Nyai juga memakai terompah atau selop yang menghiasi kaki, mereka juga mengenakan perhiasan pemberian suaminya. Di samping itu, tidak jarang ia membawa serta sebuah saputangan putih dan kunci lemari atau kunci kamar persediaan yang diperlihatkan sebagai tanda tambahan atas kedudukan yang baru (Baay, 2010).

Dengan status yang diakui oleh pemerintah Belanda maka diharuskan mempelajari bahasa Belanda sebagai bahasa komunikasi sehari-harinya. Nyai pun diajak menghadiri perayaan-perayaan oleh suaminya di mana perayaan itu 
hanya diperbolehkan dihadiri oleh warga Eropa. Contohnya saja mereka diperkenankan untuk menghadiri acara pertunjukan dan makan malam bersama di gedung Societeit Concordia yaitu sebuah tempat yang memiliki fasilitas lengkap seperti gedung pertunjukan dan restoran. Tempat ini dijadikan warga Belanda sebagai tuan kebun atau Preangerplanters untuk mengadakan acara berpesta pada sore atau petang hari untuk melepas lelah.

Pada akhir-akhir pekan biasanya diadakan suatu pertunjukan seni berupa konser musik, tonil, dan dansa (Hutagalung \& Nugraha, 2008). Musisi Eropa terkadang sengaja didatangkan untuk memberi hiburan di Societeit Concordia.

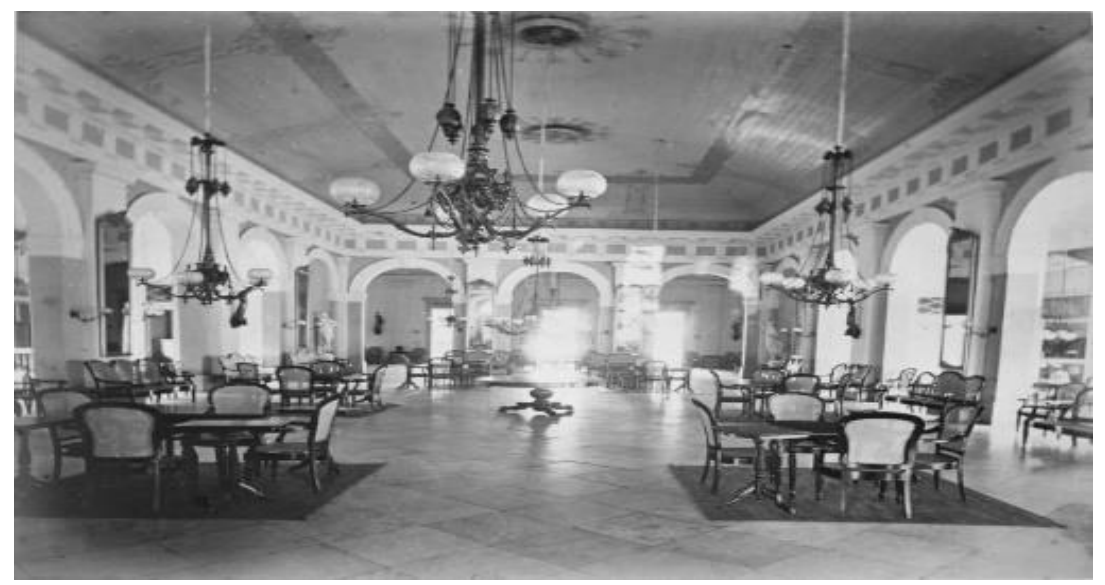

Gambar 3. Societeit Concordia dengan lantai marmer dan barang-barang mewah lainnya Sumber: http://collectie.tropenmuseum.nl/default.aspx?idx=ALL\&field $=* \&$ search $=60022743$

Kawasan ini terletak di Pedatiweg yang disebut juga Karrenweg yaitu daerah di mana hanya warga Belanda saja yang dapat memasuki, karena adanya tulisan yang berisi Verboden Toegang voor Honden en Inlander yang berarti "anjing dan pribumi dilarang masuk". Tulisan yang merendahkan Pribumi ini terletak di daerah-daerah yang memang hanya dapat dikunjungi oleh warga Eropa saja atau oleh orang yang disamakan dengan warga Eropa. Selain menonton pertunjukan dan mengadakan acara di gedung Societiet Concordia, warga Belanda juga menginap di hotel Preanger dan hotel Homann yang ada di sekitaran Pedatiweg.

Ketika seorang Nyai menginjak umur 30 tahun maka telah dianggap tua dan mereka akan mendapatkan "surat lepas". Setelah surat itu diberikan pada Nyai maka dia disuruh untuk pergi meninggalkan tangsi dan akan kehilangan segalanya. Surat tersebut juga sebagai tanda hubungan pergundikan yang terjalin diantara mereka telah berakhir. "Surat lepas" diberikan tidak hanya bila Nyai sudah terlalu tua untuk melakukan praktik pergundikan tapi juga ketika anggota militer akan dipindah tugaskan, mengambil cuti, atau akan kembali ke Belanda. Bagi Nyai yang beruntung maka Nyai dan anak campurannya akan 
ikut bersama "suaminya", tetapi jumlahnya tidak banyak kebanyakan dari mereka ditinggalkan. Jika tidak, diharapkan ada seorang rekan militer yang akan mengambilalih mereka (Baay, 2010).

Akibat yang dirasakan dengan adanya Nyai dan aktivitas pergundikan yang dilakukannya ialah dampak sosial. Keadaan ini paling dirasakan oleh Nyai di dalam tangsi militer, karena hubungan di dalam tangsi kebanyakan dilakukan secara tidak resmi atau hanya hubungan seks sesaat. Dari dampak sosial tersebut muncul permasalahan baru yaitu adanya banyak dilahirkannya anak IndoEropa. Dengan keadaan masyarakat yang kurang begitu menerima kehadiran hubungan campuran tersebut, merupakan posisi yang kurang menguntungkan menjadi anak berdarah campuran. Mereka berada di bawah bayangan negatif dari hubungan kedua orang tuanya. Penerimaan yang kurang baik dirasakan tidak saja dari masyarakat Pribumi tapi juga oleh masyarakat Eropa. Karena masyarakat Eropa yang tinggal di Hindia Belanda beranggapan bahwa anak campuran memiliki watak yang berbeda bahkan pendidikan yang mereka terima pun tidak dapat mengubah sikap dan moral mereka yang telah dipastikan buruk. Gagasan pada waktu itu adalah bahwa anak-anak berdarah campuran menyatukan sifat-sifat jelek dari kedua ras dan itu merupakan alasan utama mengapa selalu terjadi sesuatu dengan orang Indo-Eropa (Baay, 2010). Oleh karena itu tidak sedikit anak berdarah campuran yang merasa tidak diterima oleh lingkungan.

Orang Eropa memandang seorang Indo-Eropa memiliki sifat yang menonjol "kekurangan semangat dan kemauan" hal itulah yang menyebabkan buruknya keadaan ekonomi mereka. Selain itu, anak ras campuran hidup dalam bayangan negatif tentang dirinya oleh orang Eropa. Kurangnya penerimaan juga dirasakan anak berdarah campuran di lingkungan masyarakat Pribumi. Perbedaan fisik antara anak berdarah campuran dengan masyarakat Pribumi menjadikan mereka terasing. Seperti kulit yang putih ataupun postur tubuh yang tinggi serta anggapan masyarakat, bahwa mereka merupakan keturunan dari seorang ayah Belanda yang pada masa itu Belanda berkedudukan sebagai Kolonial.

Kedatangan bangsa Belanda ke Nusantara tidak selamanya membawa dampak negatif, ada juga dampak positif yang dapat dirasakan salah satunya dalam pergerakan nasional. Anak dari perkawinan campuran yang diakui secara hukum memiliki keistimewaan jika dibandingkan dengan anak asli Pribumi kebanyakan, yaitu mereka dapat mengenyam pendidikan di sekolah. Sekolah yang dapat mereka masuki tidak saja yang berada di Nusantara, tapi juga yang berada di Belanda. Setelah selesai menempuh pendidikan, biasanya mereka kembali dan bekerja di perkebunan Nusantara. Meski memiliki ayah seorang Belanda dan bersekolah di Belanda, namun tidak sedikit mereka 
merasakan ketidakadilan terutama ketika mereka sudah mulai bekerja. Hampir di setiap jenis pekerjaan, orang berdarah campuran tidak akan mendapatkan posisi tinggi. Hal ini juga didasari karena mereka memiliki darah Pribumi.

Masyarakat Jawa Barat sebagian besar bermata pencaharian sebagai buruh upah di perkebunan baik milik pemerintah Belanda maupun milik perusahaan swasta. Masuknya perusahaan swasta ke Jawa Barat seiring dengan tingginya harga ekspor teh di pasaran dunia. Dengan diberlakukannya hak Erfpacht atau Hak Guna Usaha menjadikan perusahaan swasta menyewa tanah milik penduduk Jawa Barat selama maksimal 75 tahun untuk didirikan perkebunan dengan kewajiban membayar sejumlah uang sewa.

Kerja upah di perkebunan juga berdampak adanya monetisasi atau pengenalan mata uang yang terlihat dari aktivitas penduduk sehari-hari dalam penyewaan tanah atau proses transaksi lainnya dilakukan dengan nilai tukar uang. Hal ini mempengaruhi penduduk Jawa Barat untuk mendapatkan penghasilan dengan cara bekerja menjadi buruh upah di perkebunanperkebunan milik perusahaan Belanda. Tidak hanya laki-laki yang bekerja di perkebunan untuk mendapatkan upah, perempuan dan anak-anak pun banyak yang bekerja sebagai buruh upah ketika musim panen tiba. Perempuan bekerja memetik teh, karena ketelitian sangat diperlukan ketika memanen teh sedangkan anak-anak bekerja mencari ulat sebagai buruh lepas perkebunan.

Tidak sedikit perempuan Pribumi yang bekerja di perkebunan masuk ke dalam dunia pergundikan, karena mereka tergiur dengan penghasilan yang lebih menjanjikan dibanding bekerja sebagai buruh upah di perkebunan. Kebiasaan memiliki gundik diturunkan dari kebiasaan raja yang memiliki banyak selir dan dilanjutkan oleh pembesar daerah yang memiliki gundik lebih dari satu. Hal tersebut ditiru oleh sebagian besar orang Eropa yang bekerja sebagai pegawai di perusahaan swasta Belanda. Perempuan yang bekerja baik sebagai gundik orang Eropa maupun Pribumi di Jawa Barat dikenal dengan sebutan "Nyai". Biasanya perempuan diminta langsung oleh mandor atau controleur menjadi Nyai karena tertarik ketika bekerja di perkebunan. Ada juga perempuan yang diminta menjadi Nyai ketika bekerja sebagai pembantu rumah tangga di rumah controleur tersebut.

Kebutuhan akan uang yang sudah masuk dalam kehidupan masyarakat menjadi alasan utama mengapa terjadi pergundikan pada kalangan perempuan Pribumi. Dengan menjadi Nyai mereka akan hidup dengan senang dan segala kebutuhannya akan terpenuhi. Hal inilah yang menyebabkan banyaknya perempuan masuk ke dalam dunia prostitusi, sehingga tidak sedikit terjadi hubungan campuran pada masa Kolonial.

Dalam hubungan campuran ada yang dilakukan secara resmi dan ada juga yang dilakukan secara tidak resmi. Hubungan resmi ditandai dengan 
adanya pernikahan yang didaftarkan secara hukum pada pemerintahan Belanda dengan persyaratan keduanya memiliki agama yang sama yaitu agama Kristen. Bila suatu pernikahan campuran telah didaftarkan maka suami wajib untuk membiayai dan bertanggung jawab pada keluarganya. Pada pernikahan sah posisi istri dan anak dilindungi oleh hukum maka apabila suami tidak bertanggung jawab lagi terhadap keluarganya akan ditindak secara hukum. Anak yang lahir akan terdaftar dan mendapatkan nama belakang ayah mereka. Selain itu, mendapatkan kewarganegaraan Belanda secara yuridis sama seperti ayahnya dan kedudukan mereka akan disamakan dengan warga Eropa.

Sedangkan, hubungan yang tidak resmi ialah hubungan tidak didaftarkan secara hukum pada pemerintahan Belanda. Adapun beberapa alasan suatu hubungan campuran tidak didaftarkan secara hukum yaitu karena adanya perbedaan agama atau tidak ingin adanya suatu hubungan yang mengikat. Bila mereka memiliki anak maka anak tersebut tidak akan mewarisi nama belakang ayah ataupun mendapatkan pengakuan sebagai orang Eropa. Anak yang lahir pun hanya berhak diberi nama belakang ayahnya namun dengan urutan huruf terbalik.

Meskipun banyak kerugian yang didapat perempuan bila menjadi Nyai secara tidak resmi, namun tetap saja banyak yang berminat menjadi Nyai karena mereka melihat keuntungan secara ekonomi dan sosial. Kedudukan dalam masyarakat menjadi meningkat dengan kemampuan ekonomi yang dimiliki. Kehidupan pergundikan juga terjadi di kalangan militer. Banyak perempuan Pribumi yang menjadi Nyai dalam tangsi militer.

Pada umumnya mereka melakukan hubungan secara tidak resmi karena anggota militer bertugas berpindah-pindah tempat maka Nyai dari anggota militer itu pun berganti-ganti. Hubungan dengan sering berganti pasangan maka marak juga penyebaran penyakit kelamin. Penyakit ini lebih banyak menyerang anggota militer dibandingkan dengan pegawai sipil. Meskipun pemerintah Belanda telah menanggulangi penyebaran penyakit ini dengan mengeliarkan aturan untuk terus memeriksakan kesehatan pada rumah sakit milik negara namun hal ini tidak sepenuhnya dipenuhi. Selain itu, hubungan yang ada antara perempuan Pribumi dan laki-laki Eropa memunculkan kebudayaan mestizo atau sebuah proses percampuran kebudayaan yang akhirnya menimbulkan kebudayaan baru.

Percampuran kebudayaan dikenal dengan kebudayaan Indis, contoh dari kebudayaan indis ialah perlengkapan peralatan rumah tangga seperti kursi, lemari dan meja. Kebudayaan indis ini mulai dikenal dan digunakan baik oleh keluarga pejabat daerah dan masyarakat kebanyakan. Kebudayaan indis muncul ketika orang Eropa mulai berdatangan ke Nusantara. 


\section{Simpulan}

Perekonomian Pribumi sangat tergantung pada politik yang dijalankan oleh pemerintah Kolonial. Keperluan akan uang sebagai pemenuh kebutuhan keluarga mengakibatkan kerja upah di perkebunan tidak hanya dilakukan oleh laki-laki Pribumi saja, melainkan juga oleh perempuan Pribumi dan anak-anak. Untuk memenuhi kebutuhan keluarga, tidak sedikit perempuan yang bekerja sebagai Nyai pada pejabat daerah ataupun pada pegawai Belanda. Perempuan Pribumi yang bekerja sebagai seorang Nyai memiliki kehidupan yang sulit di tempat asal mereka. Pada mulanya mereka bekerja sebagai pembantu rumah tangga di rumah orang Eropa yang bekerja di perkebunan atau menjadi petani perkebunan. Bila orang Eropa tertarik dengan perempuan Pribumi, maka akan diminta menjadi Nyai. Perempuan Pribumi yang menjadi Nyai akan dibayar tiap bulan serta diberikan pakaian dan perhiasan yang indah. Namun, tidak selamanya menjadi seorang Nyai selalu mendapatkan keuntungan tidak jarang juga mereja diperlakukan tidak layak dan tidak ada perlindungan hukum bagi perempuan Pribumi yang menjadi Nyai tersebut.

\section{Daftar Rujukan}

Baay, R. (2010). Nyai \& Pergundikan di Hindia Belanda. Jakarta: Komunitas Bambu.

Bakhtin, M. (1997). Recognition, Revolution. Princeton: Princeton University Press.

Burger, D. H. (1962). Sedjarah Ekonomis Sosiologis Indonesia (1st ed.). Jakarta: Pradnjaparamita.

Ekadjati, E. (1984). Masyarakat Sunda dan Kebudayaannya. Bandung: PT Girimukti Pusaka.

Gogwilt, C. (2007). The Vanishing Genre of the Nyai Narrative: Reading Genealogies of English and Indonesian Modernism. Comparative Literature Studies, 44(4), 409-433. https://doi.org/10.1353/cls.2007.0085

Gottschalk, L. (1983). Mengerti Sejarah : Pengantar Metode Sejarah. Jakarta: UI Press.

Hellwig, T. (2007). Citra Kaum Perempuan di Hindia Belanda. Jakarta: Yayasan Obor Indonesia.

Hutagalung, R., \& Nugraha, T. (2008). Braga : Jantung Paris Van Java. Jakarta: Ka bandung.

Ismaun. (2005). Buku Pengantar Belajar Sejarah Sebagai IImu dan Wahana Pendidikan. Bandung: Historia Utama Press.

Jelani, G. (2013). Penyakit Kelamin Di Jawa 1812-1942. Bandung: Syabas Books.

Koentjaraningrat. (1988). Manusia dan Kebudayaan di Indonesia. Jakarta: PT Penerbit Djambatan. 
Scheltema, A. M. P. A., Wiradi, G., \& Suyono, H. (1985). Bagi hasil di Hindia Belanda. Jakarta: Yayasan Obor Indonesia.

Sjamsuddin, H. (2007). No Title. Yogyakarta: Ombak.

Thornham, S. (2010). Teori Feminis Dan Cultural Studies. Yogyakarta: Jalasutra. 